\title{
Charles Poree, Discours sur la satire
}

\section{Peter Balatz}

\section{OpenEdition}

\section{Journals}

\section{Édition électronique}

URL : http://journals.openedition.org/studifrancesi/27601

DOI : 10.4000/studifrancesi.27601

ISSN : 2421-5856

\section{Éditeur}

Rosenberg \& Sellier

\section{Édition imprimée}

Date de publication : 31 décembre 2006

Pagination : 605

ISSN : 0039-2944

\section{Référence électronique}

Peter Balatz, «Charles Poree, Discours sur la satire », Studi Francesi [En ligne], 150 (L | III) | 2006, mis en ligne le 30 novembre 2015, consulté le 08 novembre 2020. URL : http://journals.openedition.org/ studifrancesi/27601 ; DOI : https://doi.org/10.4000/studifrancesi.27601

\section{Ce document a été généré automatiquement le 8 novembre 2020}

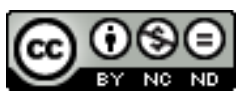

Studi Francesi è distribuita con Licenza Creative Commons Attribuzione - Non commerciale - Non opere derivate 4.0 Internazionale. 


\title{
Charles Poree, Discours sur la satire
}

\author{
Peter Balatz
}

\section{RÉFÉRENCE}

CHARLES POREE, Discours sur la satire, Présentation, édition critique, notes et traduction inédite du latin par Luis Dos SANTOS, avec index et bibliographie, Paris, Champion, 2005. pp. 215.

Dans les mémoires de jeunesse des écrivains majeurs et mineurs des Lumières, on rencontre assez souvent l'éloge du normand Charles Porée (1676-1741) sans forcément savoir ce qu'il avait fait pour mériter leur vénération. En effet, il excellait dans un domaine relativement négligé par les spécialistes de Lumières: la littérature néo-latine. Ce professeur de rhétorique du collège jésuite Louis-le-Grand, où il fut le maître de Voltaire, est l'auteur d'un grand nombre de tragédies et de discours composés en latin, et presque totalement oubliés de nos jours. Le présent volume - qui renferme aussi le tableau chronologique des principales oeuvres latines du père Porée - nous apporte le texte original latin et la traduction francaise d'un discours au sujet de la satire, prononcé á Paris, en 1710. L'intérêt et l'originalité de ce discours, composé avec un savoir-faire rhétorique énorme, réside dans le fait que les théoriciens de la littérature classique n'ont que très rarement consacré un ouvrage entier á un genre mineur.

2 L'étude de Luis dos Santos qui accompagne le texte fournit non seulement une biographie détaillée de son auteur, mais touche également aux questions principales concernant le discours (dont le sous-titre est: La satyre doit-elle être admise dans un Etat bien policé [civitas bene morata] et, si oui, jusqu'á quel point?) Quel est le rôle du théâtre dans l'enseignement que les collèges jésuites proposent à leurs élèves provenant de l'aristocratie et de la haute-bourgeoisie? Quelles sont les théories théologiques et anthropologiques qui déterminent la production théâtrale des jésuites? La satire peutelle et doit-elle améliorer l'homme ou doit-on considérer avec les jansénistes les descendants d'Adam, comme des êtres irrémédiablement déchus? Quel rôle particulier la comédie joue-t-elle dans la production théâtrale des jésuites? Comment se manifeste 
le positionnement prudent de la Compagnie de Jésus par rapport au pouvoir royal dans les oeuvres dramatiques composées et présentées au sein de l'ordre (souvent accusé de cosmopolitisme outré)? La satire peut-elle - et si oui, jusqu'á quel point - s'en prendre à ceux qui tiennent les barres de l'Etat? Comment les comédies et ce qu'on appelle plus généralement l'esprit satirique contribuent-ils á la formation et au renforcement de l'idéal de "l'honnête homme", mondain et chrétien? Le lecteur curieux trouvera des réponses á toutes ces questions dans l'introduction volumineuse et avertie, dont la lecture lui donnera envie de se jeter immédiatement sur la traduction du discours, écrite dans un francais très élégant. 